W. Kapłonek, Cz. Lukianowicz

Politechnika Koszalińska, Wydział Mechaniczny, Katedra Inżynierii Produkcji, ul. Racławicka 15-17, 75-620 Koszalin, Polska

\title{
ZASTOSOWANIE SKATEROMETRII LASEROWEJ I ANALIZY OBRAZU DO OCENY MIKRONIERÓWNOŚCI POWIERZCHNI REGENEROWANYCH PRZEZ NAPAWANIE LASEROWE I PLAZMOWE
}

\author{
STRESZCZENIE
}

\begin{abstract}
W referacie przeanalizowano możliwość wykorzystania skaterometrii laserowej do oceny mikronierówności powierzchni regenerowanych. Do badań wybrano zawory silnika spalinowego, których powierzchnie regenerowano poprzez napawanie laserowe i plazmowe. Badane powierzchnie oświetlano światłem laserowym o długości fali $\lambda=635 \mathrm{~nm}$. Powstające obrazy kątowego rozkładu natężenia światła rozproszonego rejestrowano $\mathrm{z}$ wykorzystaniem cyfrowego aparatu fotograficznego. Zarejestrowane obrazy poddano przetwarzaniu i analizie za pomocą oprogramowania Image-Pro ${ }^{\circledR}$ Plus. Opracowane makro programowe o nazwie SLIA (Scattered Light Image Analysis) pozwoliło na automatyczną analizę wybranych parametrów geometrycznych i fotometrycznych zarejestrowanych obrazów.
\end{abstract}

Stowa kluczowe: skaterometrii laserowa, analiza obrazu, chropowatość powierzchni, napawanie laserowe, napawanie plazmowe

\section{WPROWADZENIE}

Współcześnie produkowane części maszyn i urządzeń powinny charakteryzować się długim czasem pracy oraz możliwością utrzymania korzystnych parametrów eksploatacyjnych warstwy wierzchniej $[1,2]$ podczas całego procesu ich użytkowania. Często czas eksploatacji wydłuża się poprzez regenerację zużytej powierzchni, co jest korzystne ze względów ekonomicznych (koszt regeneracji jest niższy niż bezpośrednia wymiana części [3]). Na proces regeneracji składają się najczęściej czynności mycia i odtłuszczania, uzupełniania materiału oraz czynności obróbkowe. Mają one na celu przywrócenie niezbędnej dokładności wymiarowo-kształtowej, nierówności i mikronierówności powierzchni, a także nadanie wybranym powierzchniom odpowiednich właściwości (np. twardości, odporności na ścieranie itp.).

Jedną z szeroko stosowanych metod regeneracji powierzchni części maszyn i urządzeń jest napawanie $[4,5,6]$. Metoda ta polega na nakładaniu na zużytą powierzchnię warstwy stopionego materiału przy jednoczesnym topieniu podłoża. Możliwość napawania jest uzależniona od właściwości materiału, określonej pojęciem spawalności (metalurgicznej, technologicznej, konstrukcyjnej) oraz od rzeczywistego stanu powierzchni. Kontrola powierzchni regenerowanych przeprowadzana jest najczęściej 
z wykorzystaniem metod stykowych $[7,8]$ i optycznych $[9,10]$. Spośród tych ostatnich dużą grupę stanowią metody, które do oceny mikronierówności powierzchni wykorzystują zjawisko rozpraszania światła [13]. Noszą one nazwę metod skaterometrycznych $[11,12]$ i są bardzo efektywne zwłaszcza w połączeniu $\mathrm{z}$ technikami komputerowego przetwarzania i analizy obrazu $[13,14,15]$.

\section{METODYKA BADAŃ}

Celem badań doświadczalnych było określenie wybranych parametrów geometrycznych (pole powierzchni) i fotometrycznych (sumaryczne natężenie oświetlenia) obrazów kątowego rozkładu natężenia światła rozproszonego oraz skorelowanie ich z parametrami chropowatości powierzchni. W badaniach wykorzystano stalowe zawory silnika spalinowego, z których 3 poddano regeneracji za pomocą napawania laserowego, a kolejne 3 za pomocą napawania plazmowego. Przed przystapieniem do rejestracji obrazów światła rozproszonego wszystkie próbki poddano pomiarom profilometrycznym w celu uzyskania podstawowych parametrów chropowatości powierzchni. Pomiary przeprowadzono za pomoca profilometru stykowego HommelTester T8000 firmy Hommelwerke. Profilometr ten wyposażony był w jednostkę przesuwu głowicy pomiarowej Waveline 60 Basic/51808 oraz czujnik TK100, bez ślizgacza, z ostrzem odwzorowującym o promieniu zaokraglenia wierzchołka równym $5 \mu \mathrm{m}$. Profilometr posiadał dodatkowo stolik umożliwiający przestrzenne pomiary nierówności powierzchni. Wyniki pomiarów topografii powierzchni analizowano za pomoca programu HommelMap Basic v.3.0. Pomiar realizowany był z następującymi parametrami: wymiary powierzchni mierzonej $1,5 \times 1,5 \mathrm{~mm}$, liczba mierzonych profili powierzchni 151 , krok próbkowania $0,375 \mu \mathrm{m}$, zakres pomiarowy $80 \mu \mathrm{m}$. Dodatkowo dokonano rejestracji obrazów mikroskopowych powierzchni próbek za pomoca mikroskopu metalograficznego Epityp 2 firm Carl Zeiss Jena, będącego elementem systemu do akwizycji i analizy obrazów mikroskopowych. System ten szczegółowo opisano m.in. w pracy [16]. Parametry badanych próbek zostały przedstawione w tabl.1, natomiast przykładowe wyniki pomiarów profilometrycznych oraz obrazy mikroskopowe powierzchni pokazano na rysunku 1 i 2.

Table 1. Parametry badanych próbek

\begin{tabular}{|c|c|c|c|}
\hline \multirow{2}{*}{$\begin{array}{c}\mathrm{Nr} \\
\text { próbki }\end{array}$} & Rodzaj regeneracji & \multicolumn{2}{|c|}{$\begin{array}{c}\text { Chropowatość } \\
\text { powierzchni }[\mu \mathrm{m}]\end{array}$} \\
\cline { 3 - 4 } & & $R_{a}$ & $S_{a}$ \\
\hline 1. & Napawanie laserowe & 0,57 & 0,53 \\
\hline 2. & Napawanie laserowe & 0,16 & 0,20 \\
\hline 3. & Napawanie laserowe & 0,28 & 0,31 \\
\hline 4. & Napawanie plazmowe & 0,29 & 0,27 \\
\hline 5. & Napawanie plazmowe & 0,35 & 0,41 \\
\hline 6. & Napawanie plazmowe & 0,25 & 0,30 \\
\hline
\end{tabular}




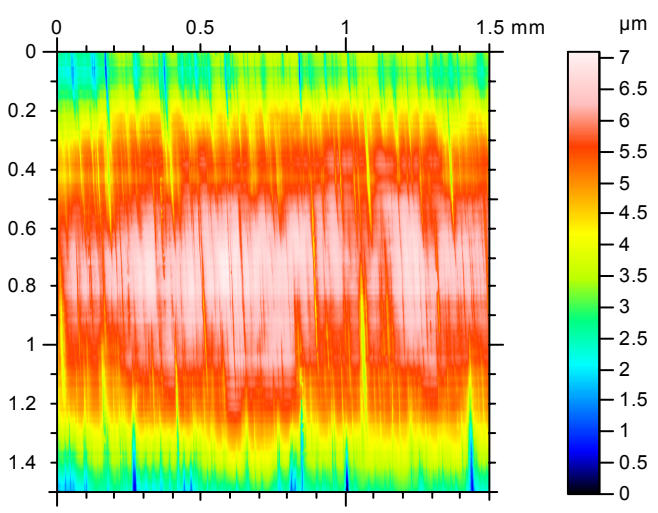

(a)

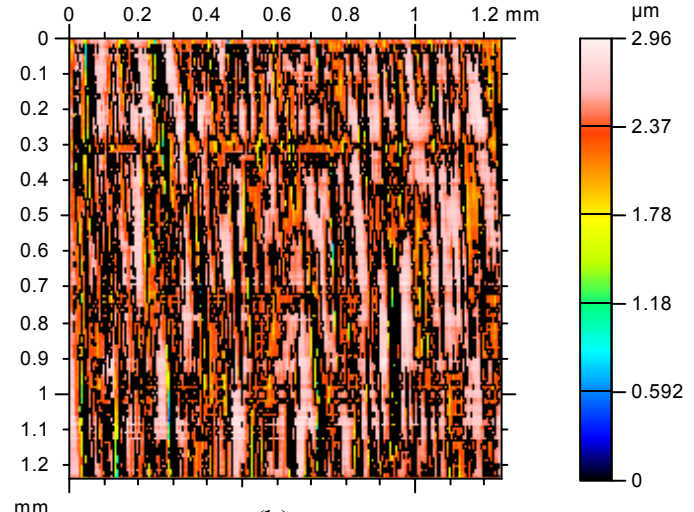

(b)

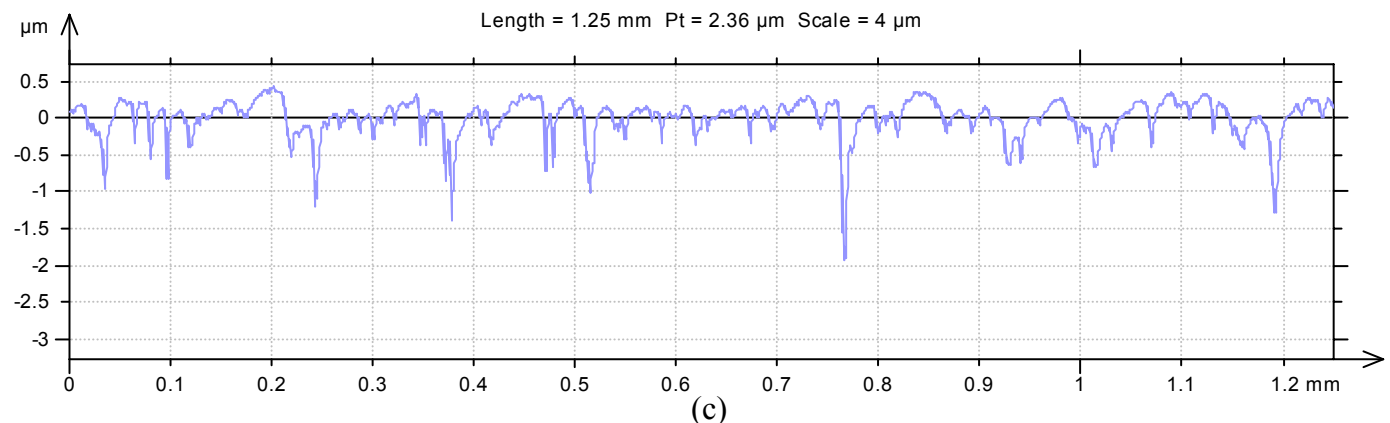

Rys. 1. Wyniki pomiarów dla próbki nr 2 otrzymane za pomoca profilometru stykowego:

a) mapa warstwicowa (bez filtracji), b) diagram konturu, c) profil powierzchni

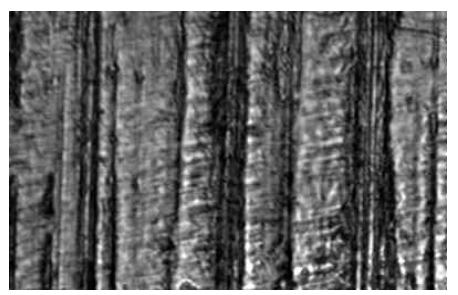

(a)

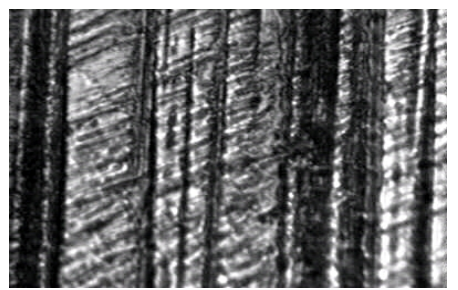

(d)

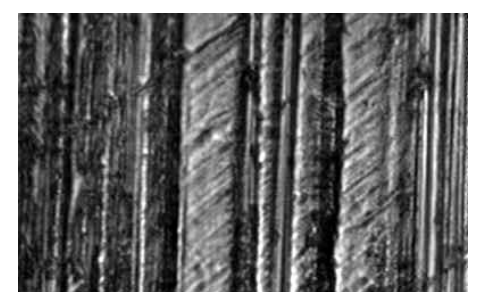

(b)

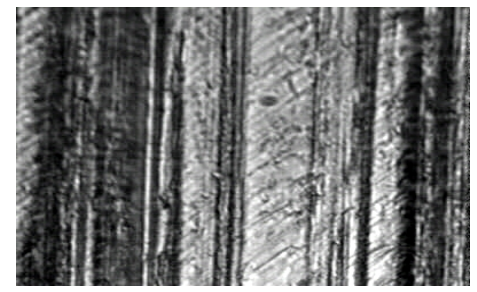

(e)

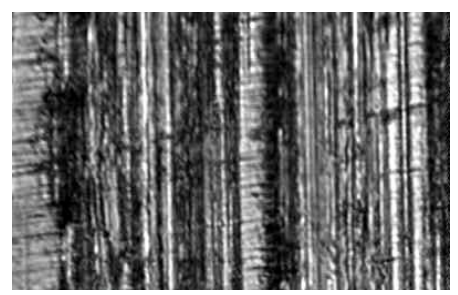

(c)

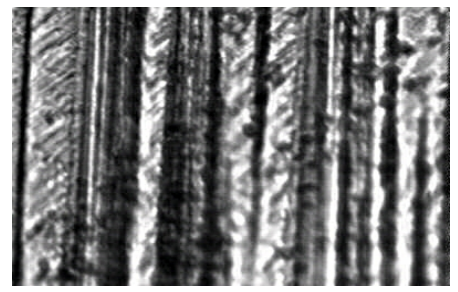

(f)

Rys. 2. Obrazy mikroskopowe powierzchni zaworów silnika spalinowego regenerowanych: a) laserowo $\left.\left(R_{a}=0,57 \mu \mathrm{m}\right), b\right)$ laserowo $\left.\left(R_{a}=0,16 \mu \mathrm{m}\right), c\right)$ laserowo $\left.\left(R_{a}=0,28 \mu \mathrm{m}\right), d\right)$ plazmowo $\left(R_{a}=0,29 \mu \mathrm{m}\right)$, e) plazmowo $\left(R_{a}=0,35 \mu \mathrm{m}\right)$, f) plazmowo $\left(R_{a}=0,25 \mu \mathrm{m}\right)$

W celu akwizycji obrazów światła rozproszonego zestawiono stanowisko badawcze, w którego skład wchodził laser półprzewodnikowy typu CPS180 firmy Thorlabs, Inc., o mocy $1 \mathrm{~mW}$, emitujący w sposób ciągły wiązkę światła o długości fali $\lambda=635 \mathrm{~nm}$. Wiązka laserowa padająca pod kątem $75^{\circ}$ oświetlała powierzchnie próbek, które zamocowano w specjalnym uchwycie. Światło rozproszone widoczne na matowym 
ekranie, rejestrowano za pomocą cyfrowego aparatu fotograficznego Dimage7i firmy Minolta. Aparat wyposażony był w matrycę typu CCD o wielkości $2 / 3$ cala i efektywnej liczbie 5,24 miliona pikseli. Schemat stanowiska badawczego pokazano na rys. 3, natomiast zarejestrowane obrazy światła rozproszonego na rys. 4 i 5.

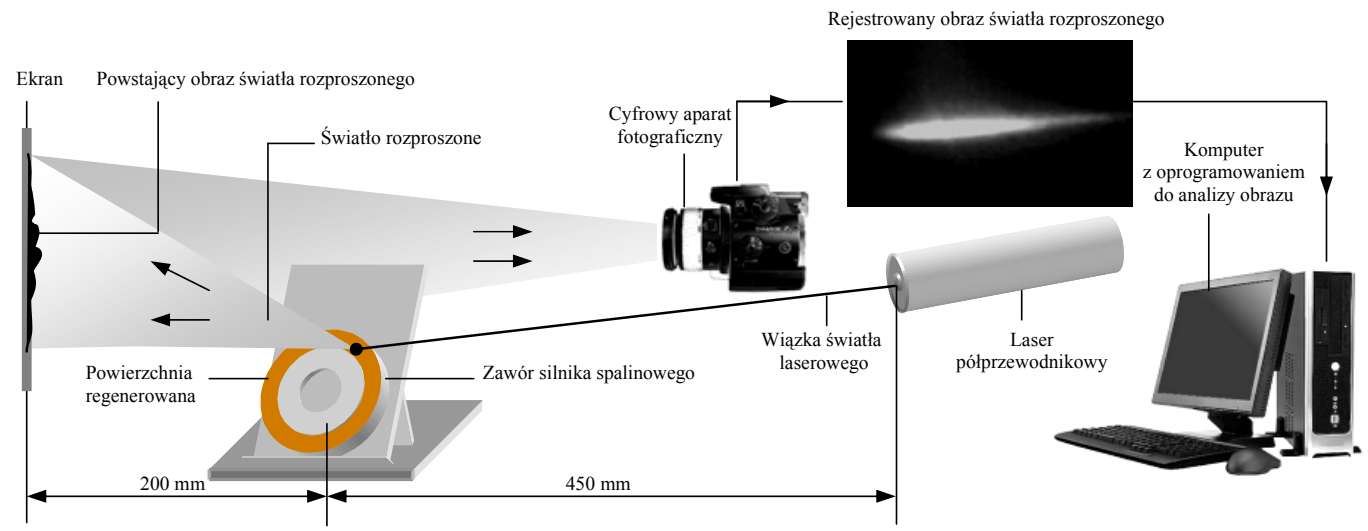

Rys. 3. Stanowisko badawcze do rejestracji obrazów światła rozproszonego

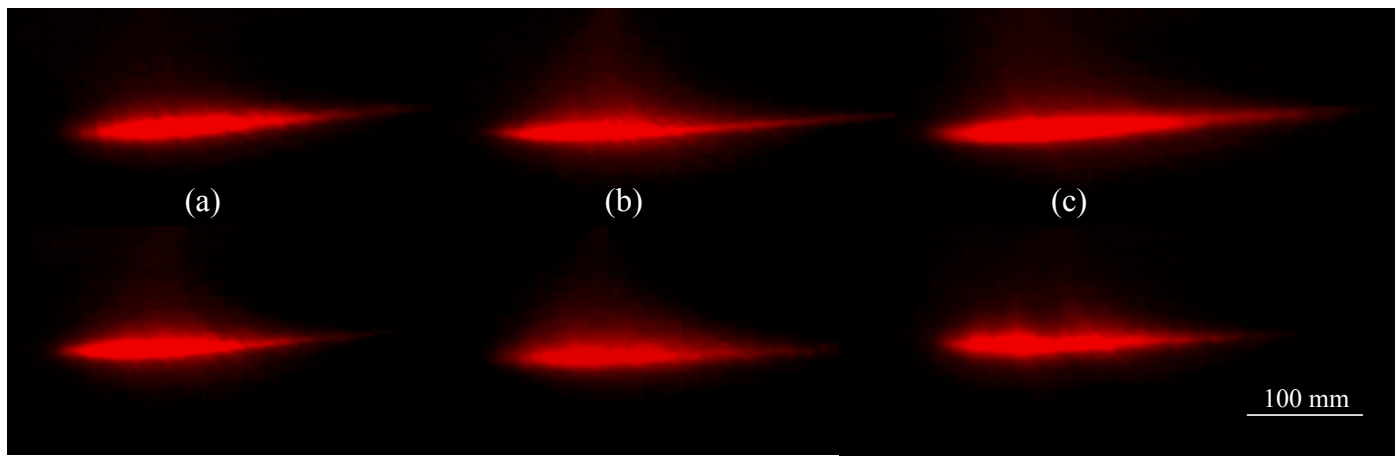

Rys. 4. Obrazy światła rozproszonego uzyskane w wyniku odbicia wiązki światła laserowego o długości fali $\lambda=635 \mathrm{~nm}$ od powierzchni zaworów silnika spalinowego regenerowanych: a) laserowo $\left.\left(R_{a}=0,577 \mu \mathrm{m}\right), b\right)$ laserowo $\left.\left(R_{a}=0,165 \mu \mathrm{m}\right), \mathrm{c}\right)$ laserowo $\left.\left(R_{a}=0,283 \mu \mathrm{m}\right), \mathrm{d}\right)$ plazmowo $\left(R_{a}=0,299 \mu \mathrm{m}\right)$, e) plazmowo $\left(R_{a}=0,355 \mu \mathrm{m}\right)$, f) plazmowo $\left(R_{a}=0,254 \mu \mathrm{m}\right)$

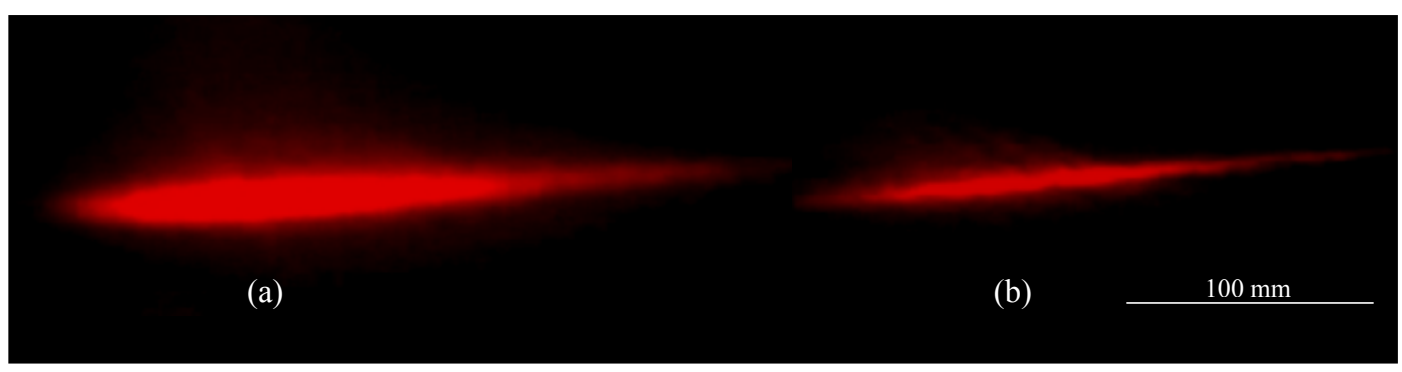

Rys. 5. Porównanie obrazów kątowego rozkłady natężenia światła rozproszonego uzyskanych w wyniku odbicia światła laserowego o długości fali $\lambda=635 \mathrm{~nm}$ od powierzchni zaworów silnika spalinowego: a) regenerowanej przez napawanie laserowe $\left(R_{a}=0,283 \mu \mathrm{m}\right)$, b) nie regenerowanej $\left(R_{a}=0,173 \mu \mathrm{m}\right)$ 
Zarejestrowane obrazy światła rozproszonego poddano przetwarzaniu i analizie za pomoca oprogramowania Image-Pro ${ }^{\circledR}$ Plus 5.1 firmy Media Cybernetics, Inc., [17]. Oprogramowanie to jest specjalistycznym środowiskiem przeznaczonym do badań naukowych, realizującym wiele standardowych funkcji dla programów tej klasy, takich jak: przechwytywanie i przetwarzanie obrazu, pomiary, analiza i archiwizowanie danych. Ponadto umożliwia automatyzację procesu analizy obrazu poprzez tworzenie makroinstrukcji. Jest to niezwykle pomocne w przypadku oceny wielu obrazów oraz przeprowadzania złożonych wielokryterialnych analiz. Makra programowe tworzone są za pomocą języka Visual Basic w edytorze o nazwie IPBasic 4.0. Autorzy opracowali makro o nazwie SLIA (Scattered Light Image Analysis), które w sposób automatyczny realizuje w kolejnych krokach analizę obrazów światła rozproszonego w zakresie oceny wybranych parametrów geometrycznych i fotometrycznych. Kolejne kroki makroinstrukcji przedstawiono $\mathrm{w}$ formie schematu na rys. 6, natomiast na rys. 7 pokazano fragment kodu źródłowego.

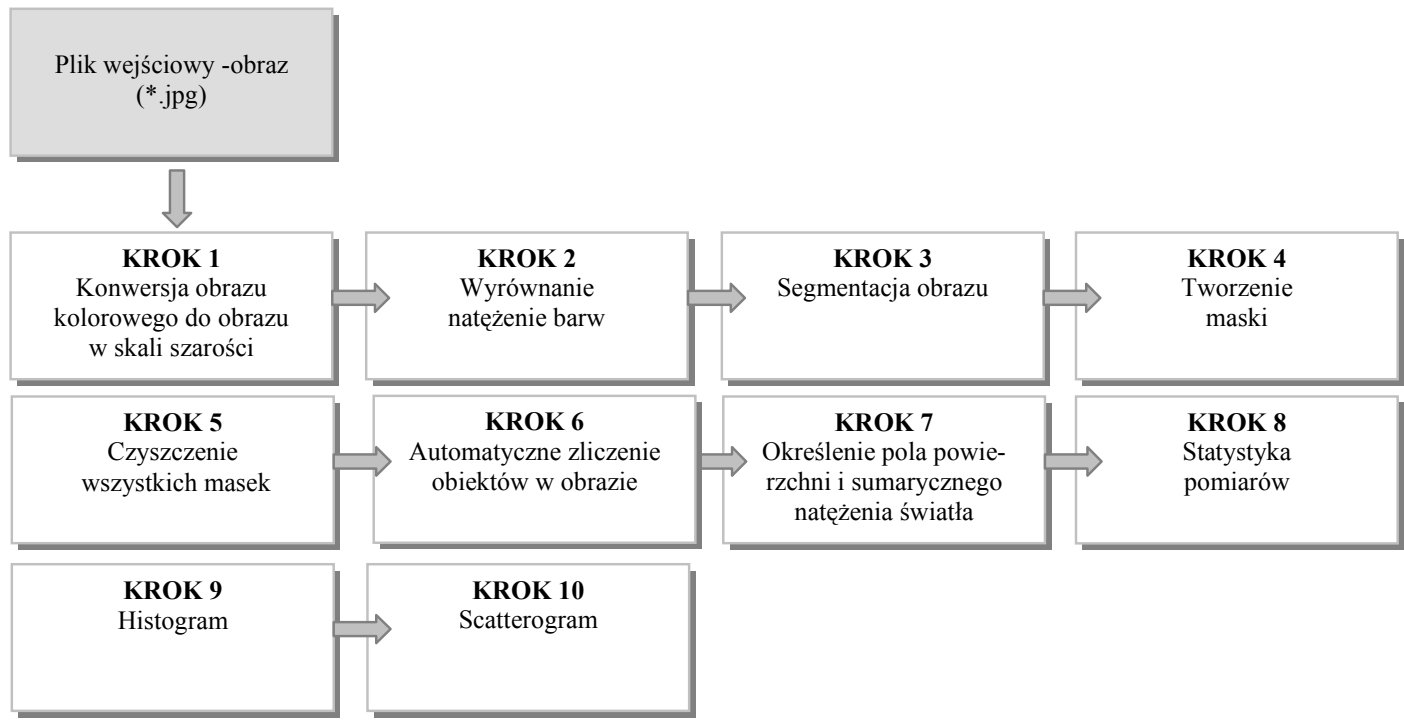

Rys. 6. Kolejne kroki makroinstrukcji SLIA (Scattered Light Image Analysis)

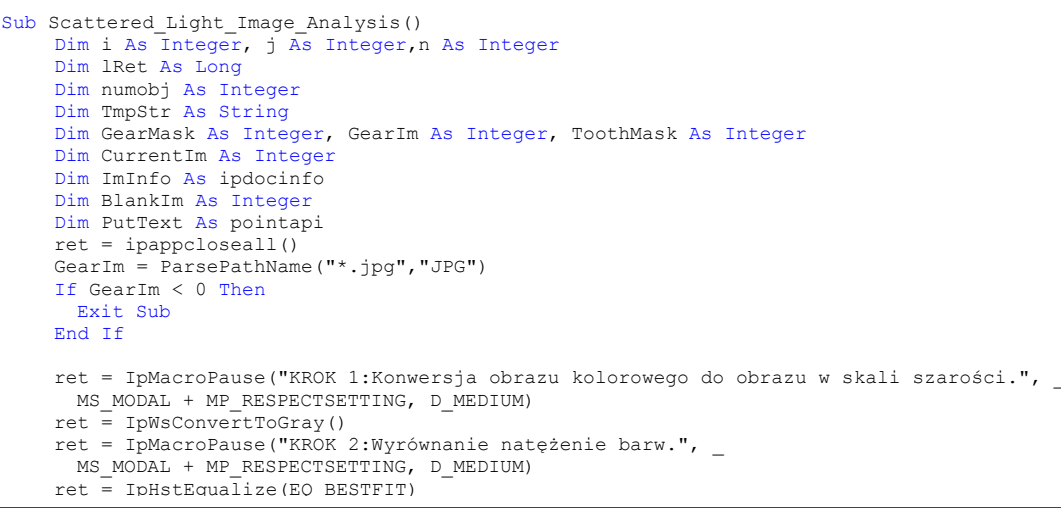

Rys. 7. Fragment kodu makroinstrukcji SLIA (Scattered Light Image Analysis) 


\section{WYNIKI I DYSKUSJA}

Na rys. 8 i 9 pokazano wyniki badań w formie wykresów. Pierwszy z wykresów przedstawia zależność pola powierzchni obrazu światła rozproszonego od chropowatości powierzchni. Wartości pola powierzchni malały wraz ze wzrostem chropowatości. Drugi z wykresów, przedstawia zależność sumarycznego natężenia światła od chropowatości powierzchni. Sumaryczne natężenie światła IOD (ang. Integrated Optical Density) to jeden z badanych parametrów fotometrycznych. W celu jego wyznaczenia program automatycznie analizował jasne obiekty występujące w obrazie światła rozproszonego. O tym, który obiekt uznawany był za jasny decydowała wartość progowa natężenia światła dobierana podczas analizy. Wartość tę program ustalał na podstawie porównania średniego natężenia tła i natężenia najjaśniejszych obszarów obrazu. Wartości sumarycznego natężenie światła, podawane w jednostkach umownych również malały w miarę wzrostu chropowatości powierzchni.

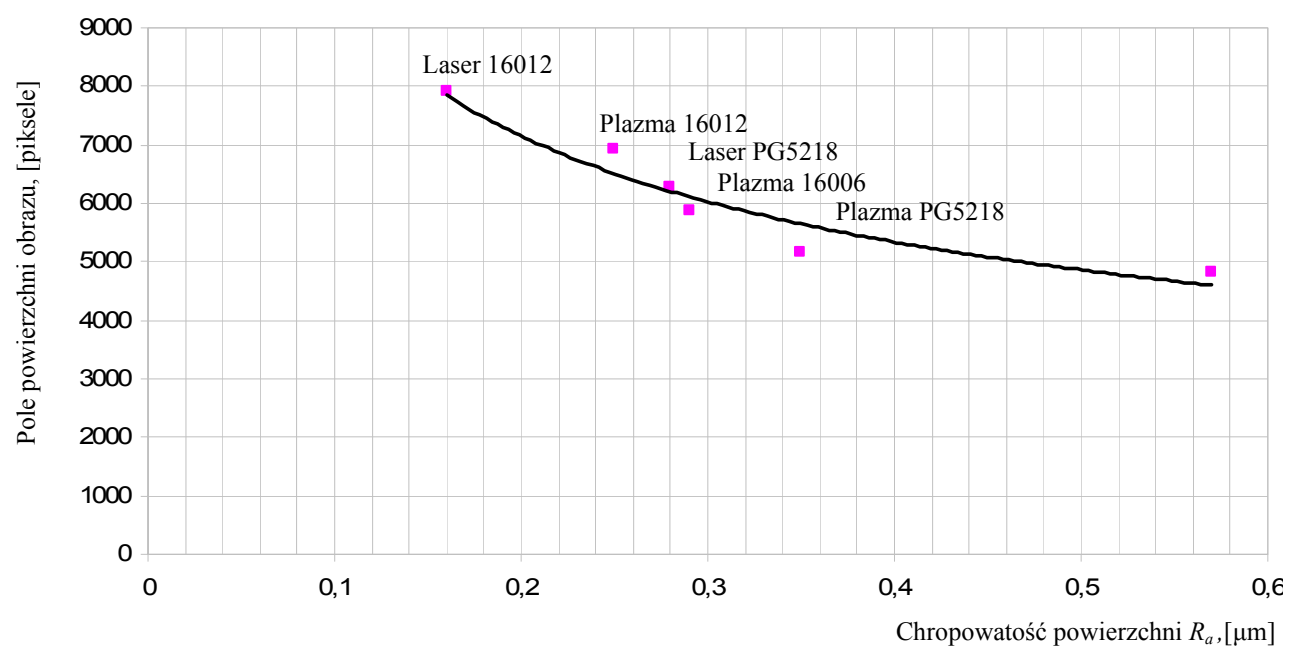

Rys. 8. Wykres zależności pola powierzchni obrazu światła rozproszonego od chropowatości powierzchni

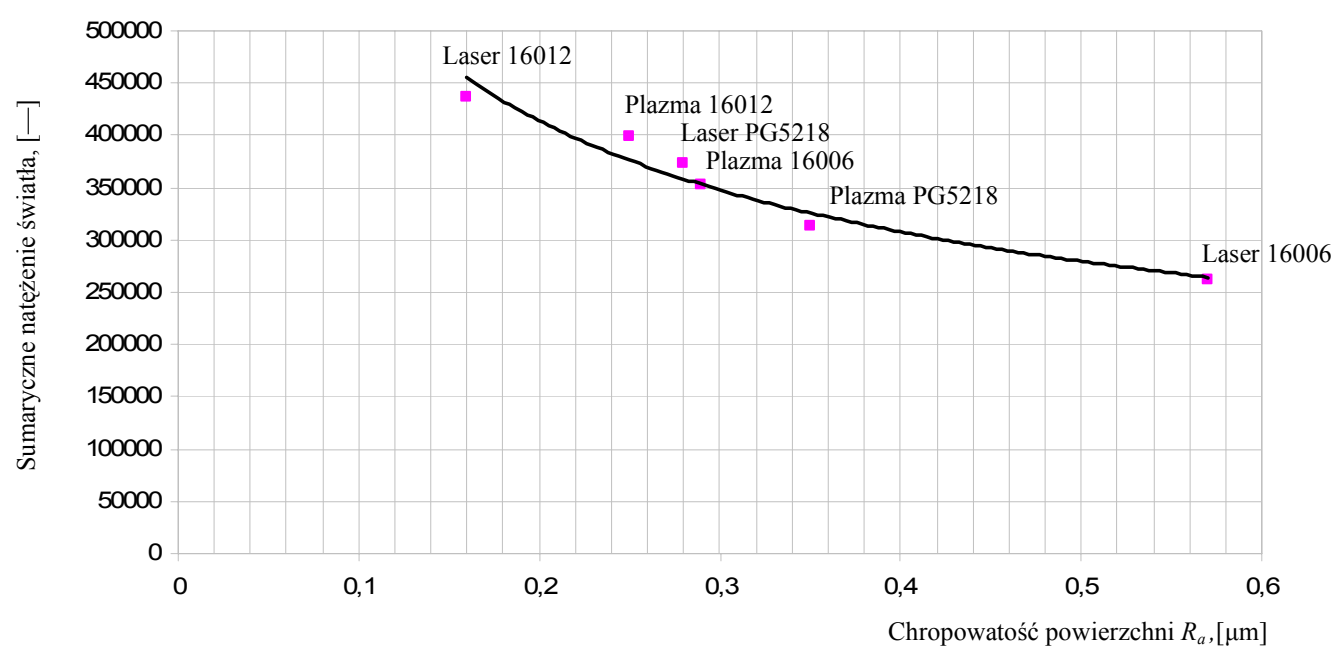

Rys. 9. Wykres zależności sumarycznego natężenia światła od chropowatości powierzchni 


\section{WNIOSKI}

Przeprowadzone badania pozwalają na wysunięcie kilku wniosków. Po pierwsze, zastosowana optyczna metod skaterometrii laserowej może być wykorzystana do oceny mikronierówności powierzchni, w tym powierzchni regenerowanych. Po drugie, połączenie jej z technikami przetwarzania i analizy obrazu daje duże możliwości oceny parametrów charakteryzujących badaną powierzchnię na podstawie zarejestrowanego obrazu cyfrowego. Po trzecie, zastosowanie oprogramowania do przetwarzania i analizy obrazu, umożliwiającego tworzenie makr programowych pozwala zautomatyzować proces analizy. Jest to szczególnie ważne w przypadku oceny dużej liczby obrazów. Zaletami takiego rozwiązania jest krótki czas przeprowadzanej analizy oraz możliwość modyfikacji kodu makra w celu oceny żądanych parametrów.

\section{BIBLIOGRAFIA}

1. Nowicki B.: Struktura geometryczna. Chropowatość i falistość powierzchni. Wydawnictwa Naukowo-Techniczne, Warszawa, 1991.

2. Oczoś K. E., Lubimov V.: Struktura geometryczna powierzchni. Podstawy klasyfikacji $\mathrm{z}$ atlasem charakterystycznych powierzchni kształtowanych. Oficyna Wydawnicza Politechniki Rzeszowskiej, Rzeszów, 2003.

3. SpaceDaily, TECH SPACE: Laser Robot Welders Cut Millions From Turbine Repairs Costs. http://www.spacemart.com/reports/Laser_Robot_Welders_Cut...html

4. Klimpel A.: Napawanie i natryskiwanie cieplne. Technologie. Wydawnictwa Naukowo-Techniczne, Warszawa, 2000.

5. Mistur L.: Spawanie i napawanie w naprawach części maszyn i konstrukcji metalowych. Wydawnictwo "KaBe" s.c., Krosno, 2003.

6. Pilarczyk J., Pilarczyk J.: Spawanie i napawanie elektryczne metali. Wydawnictwo “Śląsk" spółka z o. o., Katowice, 1996.

7. Pawlus P.: Topografia powierzchni - pomiary, analiza, oddziaływanie. Oficyna Wydawnicza Politechniki Rzeszowskiej, Rzeszów 2005.

8. Whitehouse D.J.: The Handbook of Surface and Nanometrology. Institute of Physics Publishing, Bristol, 2003.

9. Cloud G.: Optical Methods of Engineering Analysis. Cambridge University Press, 1998.

10. Whitehouse D.J. [ed.]: Optical Methods in Surface Metrology. SPIE Milestones Series Volume MS 129 [Thompson B.J. ed.], SPIE Optical Engineering Press, Bellingham, 1996

11. Łukianowicz Cz.: Podstawy pomiaru nierówności powierzchni metodami rozpraszania światła. Wydawnictwo Uczelniane Politechniki Koszalińskiej, Koszalin, 2001. 
12. Stover J. C.: Optical Scattering: Measurement and Analysis. McGraw-Hill, Inc., New York, 1990.

13. Kapłonek W.: Ocena topografii arkuszy ściernych $\mathrm{z}$ wykorzystaniem światła strukturalnego i komputerowej analizy obrazu. Pomiary, Automatyka, Kontrola 5 (2006) $38-41$.

14. Kapłonek W., Łukianowicz Cz.: Laser Scatterometry Used for Assessment of Microfinished Shafts. Proc. IV. International Congress on Precision Machining ICPM 2007, Vol.1, Section: Design \& Testing II, pp. 291-296.

15. Łukianowicz Cz., Iaquinta J.: Surface topography assessment of abrasive sheets by light scattering and self-shadowing methods. Archives of Civil and Mechanical Engineering, Vol. V, No. 2 (2005) $71-84$.

16. Łukianowicz Cz.: Badania rozpraszania światła $\mathrm{w}$ skaterometrii powierzchni. Zeszyty Naukowe Wydziału Mechanicznego Nr 25: Posiedzenie Komitetu Budowy Maszyn PAN -czerwiec 1998.Wydawnictwo Uczelniane Politechniki Koszalińskiej, Koszalin, 1998.

17. Image-Pro ${ }^{\circledR}$ Plus. Start-up Guide for Windows. Media Cybernetics, Inc., Silver Spring, MD, USA, 2004. http://www.mediacy.com

\section{PODZIĘKOWANIA}

Autorzy dziękują Panu Krzysztofowi Maciejewskiemu z Laboratorium Metrologii i Systemów Pomiarowych Politechniki Koszalińskiej za pomoc w przeprowadzeniu pomiarów profilometrycznych. 